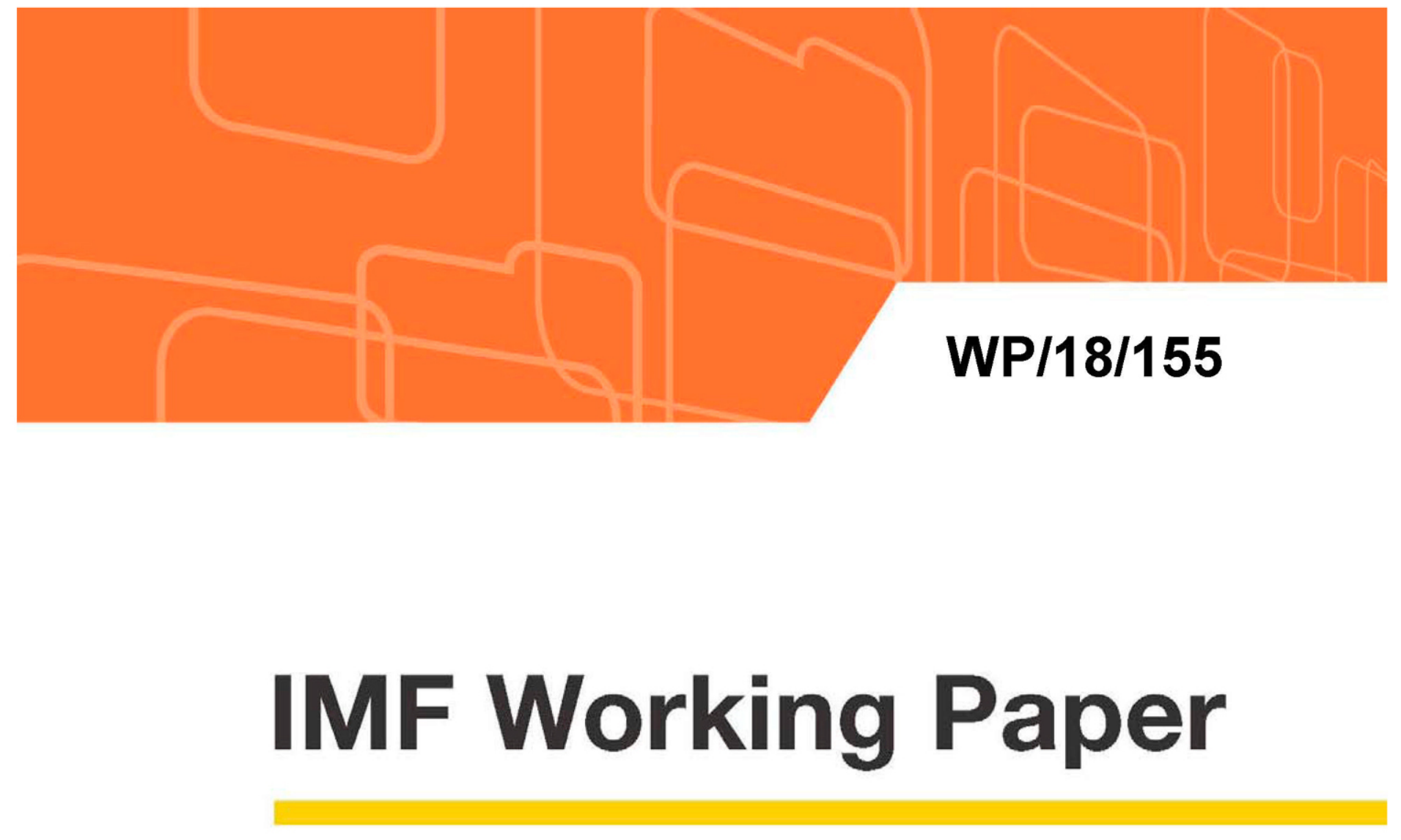

\title{
Self-insurance Against Natural Disasters: The Use of Pension Funds in Pacific Island Countries
}

by Si Guo and Futoshi Narita

IMF Working Papers describe research in progress by the author(s) and are published to elicit comments and to encourage debate. The views expressed in IMF Working Papers are those of the author(s) and do not necessarily represent the views of the IMF, its Executive Board, or IMF management. 


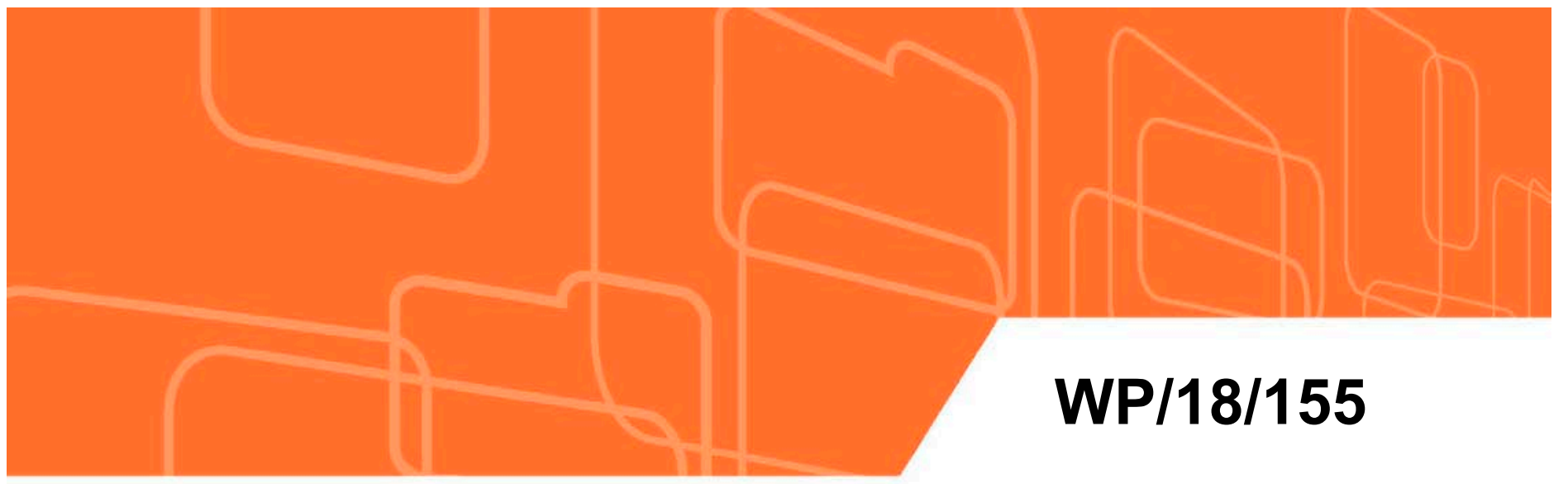

\section{IMF Working Paper}

\section{Self-insurance Against Natural Disasters: The Use of Pension Funds in Pacific Island Countries}

by Si Guo and Futoshi Narita

IMF Working Papers describe research in progress by the author(s) and are published to elicit comments and to encourage debate. The views expressed in IMF Working Papers are those of the author(s) and do not necessarily represent the views of the IMF, its Executive Board, or IMF management. 


\title{
IMF Working Paper
}

Asia and the Pacific Department

\author{
Self-insurance Against Natural Disasters: \\ The Use of Pension Funds in Pacific Island Countries \\ Prepared by Si Guo (APD) and Futoshi Narita (SPR) ${ }^{1}$ \\ Authorized for distribution by Alison Stuart
}

April 2018

\section{IMF Working Papers describe research in progress by the author(s) and are published to elicit comments and to encourage debate. The views expressed in IMF Working Papers are those of the author(s) and do not necessarily represent the views of the IMF, its Executive Board, or IMF management.}

\begin{abstract}
Pacific island countries are exposed to significant risks from natural disasters. As a disaster relief measure, Fiji allowed pre-retirement pension withdrawls in the wake of Cyclone Winston in 2016. Motivated by this policy action, we provide a normative analysis of the use of early pension withdrawals after disasters, by setting up a life-cycle saving model with myopic households facing large natural disaster shocks. The model demonstrates the key trade-off between building up sufficient retirement savings and ensuring the access to savings against natural disaster shocks, and sheds light on welfare implications of early pension withdrawals.
\end{abstract}

JEL Classification Numbers: E21, H55

Keywords: Fiji, Insurance, Life-cycle model, Natural disasters, Pension, Small states

Authors’ E-Mail Address: Si Guo, sguo@imf.org; Futoshi Narita, fnarita@,imf.org

\footnotetext{
${ }^{1}$ We thank Csaba Feher, Scott Roger, Alison Stuart and staff at the Reserve Bank of Fiji for helpful comments. Irene Zhang and Fatma Ibrahim provided excellent research and editorial assistance.
} 
I. Introduction

II. Pension Schemes in Fiji and other small states $\underline{6}$

A. Fiji's Pension Scheme $\underline{6}$

B. Cyclone Winston Assistance Withdrawals

C. Pension Funds in Other Pacific Island Countries

III. Pension Withdrawals Assistance under Natural Disaster Shocks $\underline{10}$

A. Basic Pension-Saving Model 10

B. Analysis on Pension Withdrawals Assistance 11

C. Caveats on the Model Analysis 12

IV. Conclusions $\underline{16}$

Tables

1. Key Indicators in the FNPF

2. The FNPF's Qualified Life Events for Early Pension Withdrawal $\underline{6}$

3. Pension Funds in Selected PICs

Figures

1. Household saving decisions in the model $\underline{14}$

2. Household saving decisions in the model $\underline{15}$

Appendices

I. Full Model Description $\underline{18}$

Appendix Tables

A1. Parameter values used in the stimulation $\underline{20}$ 


\section{INTRODUCTION}

Pacific islands countries are frequently affected by severe natural disasters such as cyclones and earthquakes. Lee et al. (2018) estimate that the probability of a severe natural disaster is 8.8 percent per year for each country in the region. The economic impact of natural disasters can be catastrophic, given the small size of these economies. For example, Cyclone Pam resulted in a loss of the magnitude of 60 percent of GDP in Vanuatu in 2015. The losses from Cyclone Winston were about 30 percent of GDP for Fiji in 2016.

\section{Despite the large economic impact of natural disasters, insurance coverage has been} limited at the country level in the Pacific. The small sizes of the economies and the catastrophic nature of disasters in the region pose additional challenges for insurers to pool risks or seek reinsurance. The only well-established regional disaster insurance scheme is the Pacific Catastrophe Risk Insurance Pilot Program, partially financed by the World Bank and Japan. ${ }^{2}$ The scheme, launched in 2013, currently covers five countries: the Cook Islands, the Marshall Islands, Samoa, Tonga, and Vanuatu. Three payouts have been made out: Tonga received US\$ 1.3 million after Cyclone Ian in 2014 and US\$3.5million after cyclone Gita in 2018; and Vanuatu received US\$ 1.9 million after Cyclone Pam in 2015. However, the extent of coverage is low compared to total losses 3 : the economic losses from Ian and Pam were US\$ 31 million and US\$ 449 million for Tonga and Vanuatu, respectively. In addition, the Solomon Islands, which used to be covered in this scheme, withdrew from it in 2014, after neither the Santa Cruz earthquake in 2013 nor the flood in 2014 triggered a payout.

At the household level, insurance coverage is also limited for countries in the region. For example, in Fiji, one of the relatively more advanced economies in the region, only 6 percent of households have property insurance (Mahul et al. 2015). More broadly, only 12 percent of Fijians are covered by any form of insurance (RBF 2016). Several reasons for the low takeup rate of insurance policies in developing countries have been discussed in the literature, including: low financial literacy, lack of trust, and large basis risk (for example, see Cole et al. 2012, Karlan et al. 2014). An additional constraint, which is less frequently mentioned but is important in the context of Pacific island countries, is that a large proportion of the residential buildings currently do not meet the minimum construction standards for insurance policies provided by insurers.

Given the limited access to disaster insurance products, Fiji and Vanuatu used pension fund savings as a disaster relief instrument. In 2016, Fiji allowed pension members to withdraw up to 30 percent of their pension account balance after Cyclone Winston. Vanuatu allowed residents to withdraw up to 20 percent of their pension savings after Cyclone Pam in

\footnotetext{
${ }^{2}$ See more details about the scheme from http://projects.worldbank.org/P133255/pacific-catastrophe-riskinsurance-pilot-program?lang=en.

${ }^{3}$ Part of the reason for the low coverage is that the scheme is designed to provide funding for immediate costs that can be a small portion of total losses.
} 
2015. In both cases, pension savings essentially served as a self-insurance tool for households. The withdrawal of pension savings after natural disasters helped mitigate the sharp contraction of consumption and economic activities, at the cost of lower consumption in the future.

This paper presents a normative analysis of using the early withdrawal policy as a disaster relief measure. In the standard theory, it is optimal for a household to dis-save in bad years and accumulate assets in good years. In this regard, it is unambiguously optimal to allow residents to withdraw part of their pension savings when disasters hit. However, in practice, households tend to make insufficient savings for the future - a behavior often associated with myopia. As a result, in normal times, mandatory pension contribution requirements, which have been implemented in many Pacific island countries, are necessary to ensure sufficient retirement savings. However, pension savings are usually not accessible before retirement. Increasing the mandatory pension contribution rate can sometimes be costly because these pension savings cannot be used to insure against risks other than longevity.

The "illiquid" nature of pension savings can be changed by allowing households to withdraw pension savings before retirement. However, when households are myopic, options for early withdrawals of pension savings can encourage households to inefficiently over-consume. Therefore, there is a trade-off between providing consumption smoothing through early withdrawals in the wake of natural disasters and mitigating the under-saving problem.

The analysis sheds light on the welfare implications of early pension withdrawal. It shows that if the shock is large enough, or the amount allowed for early withdrawal is not "too generous", a one-time early withdrawal can improve welfare. More generally, a recurrent early withdrawal policy contingent on the realization of natural disasters can further improve welfare. Under such a policy, however, households could anticipate that the early withdrawal option would always be granted whenever a disaster hits, and thus, would face less need to make precautionary (non-pension) savings against natural disasters ex-ante. Meanwhile, because pension savings are more "liquid" when early withdrawals are allowed in the wake of a disaster, the welfare cost for increasing mandatory contribution rate is smaller. Therefore, there would be room to increase the mandatory contribution rate.

The rest of the paper proceeds as follows. Section 2 documents the pension scheme in Fiji and other Pacific island countries. It also describes Fiji's early withdrawal policy introduced after Cyclone Winston. Section 3 provides a normative analysis of using early pension withdrawal as a disaster-relief measure. Section 4 concludes. 


\section{Pension Schemes In FiJI AND Other SMAll STATES}

\section{A. Fiji's Pension Scheme}

Fiji's pension scheme is best summarized as a defined-contribution scheme. The scheme is operated by the Fiji National Provident Fund (FNPF), a public entity supervised by the Reserve Bank of Fiji (RBF). By law, each worker and his (or her) employer pay to the FNPF a mandatory monthly contribution. The FNPF uses the collected contributions to make investments. The contributions and the associated investment returns are credited to individuals' accounts. The returns that the FNPF credited to individuals' accounts can be different from the actual returns that the FNPF earns from investment. ${ }^{4}$ After retirement (age 55), pensioners can choose to withdraw their pension savings from the FNPF through a lump-sum payment or an annuity plan. The summary statistics are listed in Table 1.

\begin{tabular}{|l|cc|}
\hline \multicolumn{4}{|c|}{ Table 1. Key Indicators in the FNPF } \\
\hline \multicolumn{3}{|c|}{ (In millions of Fiji dollars, unless otherwise indicated) } \\
\hline Membership (in number of people) & $\mathbf{2 0 1 5}$ & $\mathbf{2 0 1 6}$ \\
Total Asset & 403,316 & 406,065 \\
Net Assets Available To Pay Benefits & 5,532 & 5,832 \\
Member's Closing Balance & 5,016 & 4,875 \\
Annual Contributions & 4,233 & 4,363 \\
Withdrawals & 432 & 481 \\
Interest Rate Credited to Members (in percentage) & 300 & 575 \\
Memo: Nominal GDP & $6 \%$ & $6.25 \%$ \\
Source: FNPF 2016 Annual Report & 9,150 & 9,785 \\
\hline
\end{tabular}

The compulsory contribution requirement is essential to keep the size of the FNPF growing. Should the government abandon the compulsory contribution requirement, pension savings would be likely to shrink sharply. This can be seen from two pieces of evidence, as follows:

- First, participation in the FNPF's "voluntary" pension scheme is very limited. Besides the compulsory contribution scheme that applies to workers in the formal sector, the FNPF offers a voluntary pension scheme targeting workers in the informal sector. Owners of voluntary pension accounts are entitled the same benefits as the compulsory scheme members (in terms of early withdrawal eligibility and pension payment calculation), but they are not subject to the 18 percent compulsory contribution rate. Thus, the comparison of pension saving behaviors of compulsory

\footnotetext{
${ }^{4}$ When actual returns are higher than the returns credited to members, the difference become the capital or retained earnings of the FNPF for future disbursement.
} 
and voluntary account holders provides some insights to the possible outcome of a change to the compulsory contribution rate. In 2016 , only 0.6 percent of the contributions were collected from voluntary members. As a comparison, Fiji's informal sector accounts for over one third of the total employment. ${ }^{5}$ Although workers in the informal sector may not earn enough to make savings for the future in general, such disproportionally low pension contributions from voluntary account holders indicates that a substantial portion of the pension accumulation in Fiji is attributed to the mandatory contribution requirement rather than households' voluntary saving choices. ${ }^{6}$

- Second, the annuity option is much less popular than the lump-sum withdrawal option at the retirement. In 2016, only 254 out of 6015 pensioners and nominees who are eligible for lump-sum withdrawal or annuity opted for annuity. Most pensioners chose to withdraw all their pension savings right after they reach their retirement age. This indicates that if the mandatory contribution requirements are abandoned, households are likely to withdrawal from or reduce their contributions to the pension accounts. Given the return from pension account is much higher than other investment opportunities available to households in Fiji, it is unlikely that households will save the amount withdrawn from pension account in other assets.

\section{Under the current scheme, FNPF members are allowed to withdraw part of their pension savings before retirement with the evidence of qualified life events. The}

qualified events include: education, medical, unemployment, funeral, migration, and housing purchase. The cumulative amount that can be withdrawn is capped at 30 percent of the account balance. ${ }^{7}$ Therefore, pension savings in Fiji can be partially liquid, provided the member has a qualifying life event. Table 2 summarizes the rules on the eligibilities of pension withdrawals and relevant statistics in 2016.

\footnotetext{
${ }^{5}$ Estimates range from 36 percent (Fiji Bureau of Statistics) to over 60 percent (2016 ILO Fiji Labor Market Update).

${ }^{6}$ One caveat of this argument is that the informal sector workers may be unwilling to make contributions to pension accounts because they want to keep their income hidden to evade taxes.

${ }^{7}$ More specifically, the monthly contributions are split into two accounts: general account (30 percent) and preserved account (70 percent). Each FNPF member can choose to withdraw his or her general account balance, provided evidence of a qualified life event (education, medical, etc.). One exception is for first-time home buyers: if a member chooses to access to the pension savings before retirement for the purpose of (first-time) home purchase, he or she can also access to part of the preserved account balance. The maximum amount that can be withdrawn is 51 percent of the total account balance.
} 


\begin{tabular}{|c|c|c|c|c|}
\hline & No. of Applicants & $\begin{array}{l}\text { Total Amount } \\
\text { (F\$ millions) }\end{array}$ & Eligibility & Upper Limit* \\
\hline $\begin{array}{l}\text { Full withdrawal after } \\
\text { retirement }\end{array}$ & 11509 & 136 & $>55$ years old & \\
\hline Migration & 1522 & 28 & $\begin{array}{l}\text { Members who permanently settle } \\
\text { overseas }\end{array}$ & \\
\hline Incapacitation & 172 & 4.8 & $\begin{array}{l}\text { Members who are not able to secure } \\
\text { any further employment due to physical } \\
\text { or medical conditions }\end{array}$ & \\
\hline Death & 1765 & 17.6 & Nominees of deceased members & \\
\hline Education & 30721 & 36 & $\begin{array}{l}\text { cover the tuition of members or } \\
\text { memebers' spouses, children or siblings } \\
\text { attending qualified levels of education } \\
\text { programs. }\end{array}$ & $\begin{array}{l}\text { Amount varies depending } \\
\text { on tuition and function } \\
\text { (accomodation, textbooks } \\
\text { etc) }\end{array}$ \\
\hline Unemployment & 6572 & 9.2 & $\begin{array}{l}\text { Members who have been terminated, } \\
\text { laid off, made redundant or contract not } \\
\text { renewed or resigned. }\end{array}$ & $\mathrm{F} \$ 2,000$ \\
\hline Funeral Assistance & 4497 & 5.2 & $\begin{array}{l}\text { Assist funneral expenses of members' } \\
\text { immediate relatives. }\end{array}$ & $\$ 1,500$ per funeral \\
\hline Medical & & 2.2 & $\begin{array}{l}\text { Cover the medical expenses of } \\
\text { members or memebers' immediate } \\
\text { relatives }\end{array}$ & $\begin{array}{l}\text { F } \$ 5,000(10,000) \text { per } \\
\text { patient per year for } \\
\text { patients with (without) } \\
\text { insurance; }\end{array}$ \\
\hline Housing & 7196 & 44.9 & Build or renovate a house & $\mathrm{F} \$ 5,000$ \\
\hline TC Winston Assistance & 182,571 & 275.5 & & $\mathrm{~F} \$ 6,000$ \\
\hline \multicolumn{5}{|c|}{$\begin{array}{l}\text { * Members' contributions and investment returns are credited to two individual accounts: general account ( } 30 \%) \text { and preserved } \\
\text { account }(70 \%) \text {. The total sum of early withdrawals (education, unemployment, funderal assistance, medical, housing and disaster } \\
\text { assistance) cannot exceed the total the balance of the general account. }\end{array}$} \\
\hline
\end{tabular}

\section{B. Cyclone Winston Assistance Withdrawals}

Cyclone Winston hit Fiji in February 2016. The total loss is estimated to be 30 percent of GDP. For individuals, the losses were mainly in the form of damage to houses and the revenue drop in certain sectors (especially agriculture). Because most Fijians did not have disaster insurance, they had to use their non-pension savings to cover their repair cost and revenue losses.

As a disaster relief measure, Fiji government allowed pension fund members hit by TC Winston to withdraw from their pension accounts. The amount that could be withdrawn was up to F\$ 6,000 as long as it was within the cumulative cap for all early withdrawals of 30 percent of their pension account balances. About 180,000 TC-Winston-related withdrawal applications were approved and the total amount paid to members reached F\$ 275.5 million. Each applicant withdrew about F\$ 1,510 (equivalent to US\$ 750). ${ }^{8}$

The views on this early pension withdrawal policy are mixed. On the positive side, it "provided the much-needed stimulus for economic activity and help rebuild confidence in the

\footnotetext{
${ }^{8}$ The GDP per capita in Fiji is about US\$ 5,300 in 2016.
} 
Fiji economy, by allowing FNPF members to help themselves and their families recover from the damage sustained from TC Winston" (FNPF 2016). On the negative side, it raised the concerns that retirees may receive less pension and emergency funds in the future (Mansur et al. 2017).

\section{Pension Funds in Other Pacific Island Countries}

Fiji's experience may be applicable to other Pacific island countries for several reasons. First, Pacific island countries are frequently hit by natural disasters such as cyclones, floods, droughts and earthquakes. Second, despite the high frequency of natural disasters, insurance coverage in most Pacific island countries is typically low. ${ }^{9}$ Third, most Pacific island countries have national defined contribution pension schemes.

The existing pension schemes in selected Pacific island countries have many features in common (Table 3). These schemes are usually defined-contribution schemes, with mandatory contribution rates for employees and employers. Early withdrawals are also allowed for some countries, provided there is a qualified life event. One observation is that the mandatory contribution rate in Fiji is the highest in the region, followed by Kiribati and Micronesia.

To the best of our knowledge, Vanuatu is the only Pacific island country, besides Fiji, that has used pension funds to provide disaster-relief funds. In 2015, under the advice of Vanuatu government, Vanuatu National Provident Funds (VNPF) allowed its 40,000 active members to withdraw up to 20 percent of their retirement savings after Cyclone Pam. The total withdrawals amounted to Vt 1.7 billion, or equivalently, 2.1 percent of GDP (IMF 2016).

\footnotetext{
${ }^{9}$ Lucas (2015) documents that the (non-life) insurance penetration rates were between 0.9 percent (Tonga) to 2.5 percent (Fiji) for pacific island countries in 2012. The penetration rate in the United States was 6 percent.
} 


\begin{tabular}{|c|c|c|c|c|c|c|}
\hline \multirow[t]{2}{*}{ Country } & \multirow[t]{2}{*}{ Pension Fund Name } & \multicolumn{2}{|c|}{ Net Asset (M USD) } & \multicolumn{2}{|c|}{$\begin{array}{l}\text { Mandatory } \\
\text { Contribution Rate }\end{array}$} & \multirow[t]{2}{*}{$\begin{array}{l}\text { Qualified Events for Early } \\
\text { Withdrawals* }\end{array}$} \\
\hline & & mn USD (year) & $\%$ of $G D P$ & Employee & Employer & \\
\hline Fiji & Fiji National Provident Fund & $2815(2016)$ & $60 \%$ & $8 \%$ & $10 \%$ & $\begin{array}{l}\text { Education; Medical; } \\
\text { Unemployment; Housing }\end{array}$ \\
\hline Kiribati & Kiribati Provident Fund & $98(2015)$ & $54 \%$ & $8 \%$ & $8 \%$ & $\begin{array}{l}\text { Account balance can be used to } \\
\text { pledge against loans }\end{array}$ \\
\hline Micronesia & Micronesia Social Security Administration & $45(2014)$ & $14 \%$ & $8 \%$ & $8 \%$ & \\
\hline Marshall Islands & Marshall Islands Social Security Administration & - & - & $7 \%$ & $7 \%$ & \\
\hline Samoa & Samoa National Provident Fund & $231(2016)$ & $30 \%$ & $7 \%$ & $7 \%$ & Medical \\
\hline Solomon Islands & Solomon Islands National Provident Fund & $382(2017)$ & $32 \%$ & $5 \%$ & $8 \%$ & Unemployment \\
\hline Tonga & National Retirement Benefits Fund & $56(2017)$ & $14 \%$ & $5 \%$ & $10 \%$ & $\begin{array}{l}\text { Medical, Education, } \\
\text { Unemployment, Mortgage } \\
\text { Foreclosure }\end{array}$ \\
\hline Vanuatu & Vanuatu National Provident Fund & $159(2014)$ & $21 \%$ & $4 \%$ & $4 \%$ & $\begin{array}{l}\text { Withdrawal option after } \\
\text { Cyclone Pam }\end{array}$ \\
\hline
\end{tabular}

\section{Pension Withdrawals Assistance Under Natural Disaster Shocks}

What are the implications of allowing early withdrawals from pension savings when the economy is hit by a natural disaster? We consider this question by formulating a household life-cycle consumption-saving model subject to natural disaster shocks. We present a full description of the model in Appendix I.

\section{A. Basic Pension-Saving Model}

We set up a household life-cycle model as follows. In the model, the representative household works for $K$ periods, retires at age $K+1$, and lives up to age $T$ at maximum. Households face a survival rate $P_{S}$. After retirement, households only receive a basic subsistence income, ${ }^{10}$ which is much lower than the labor salaries when they are of working age. Households cannot borrow. However, they can make savings for both retirement and self-insurance against natural disaster shocks. A natural disaster randomly occurs with a small probability, with no predictability, and reduces labor income by a fixed amount.

We first characterize the optimal consumption and saving choices of the social planner. In normal years, the social planner accumulates savings before retirement and dis-saves after retirement. Thus, the life-cycle path of saving positions should be in hump shape if there are no shocks materialized (Figure 1, Panel A, solid green line). However, if there is a disaster shock, the social planner uses some of its savings to smooth consumption (Figure 1, Panel A, dashed green line). Saving positions decrease first then gradually catch up with the original saving path without any materialized shocks.

\footnotetext{
${ }^{10}$ This corresponds to transfer income from various social programs (e.g. Poverty Benefit Scheme) or relatives.
} 
However, households may tend to save less than the social planner. This can be attributed to several factors: an underestimation of their life expectancy, uncertainty about future policies, and lack of trust of the pension scheme etc. In this paper, we assume that households believe that their survival rate is lower than the true value, denoted by $P_{s}^{H}<P_{s}$. Therefore, households tend to under-save for retirement, compared to the social planner's optimal choices (Figure 1, Panel A, blue lines). This provides a rationale for government actions such as requiring mandatory contributions to pension accounts. Currently, Fijians working in the formal sector are required to contribute 18 percent of their salaries (10 percent from employers, 8 percent from employees) to their pension accounts.

\section{The mandatory pension contribution requirement can mitigate households' under- saving for retirement, but also limits households' ability to insure against negative} shocks. This is because, in most countries, households are not allowed to withdraw from pension accounts before retirement, and thus, the pension is an illiquid asset for them. Therefore, before retirement, households cannot use the pension savings as a buffer for negative shocks. Thus, in the model, when we assume that early withdrawals of pension savings are prohibited, households voluntarily save more than the mandatory pension savings to create a buffer (Figure 1, Panel B). The choice of the mandatory pension contribution rate has a trade-off: higher mandatory contribution rates (1) increase savings for retirement; but (2) weaken households' abilities to insure against shocks if pre-retirement withdrawals are not allowed or limited. In other words, the relationship between the expected welfare of households and the mandatory pension contribution rate is in hump shape (Figure 1, Panel C, blue line). Facing this trade-off, the optimal mandatory pension contribution rates may need to be set such that the mandatory pension savings path is below the saving path of the social planner.

\section{B. Analysis on Pension Withdrawals Assistance}

\section{Allowing early pension withdrawals when an income shock hits can achieve a better} balance between retirement savings and self-insurance. Allowing temporary withdrawals partially reverses the illiquid nature of pension savings and helps households insure against income shocks, including natural disaster shocks. However, to overcome the under-saving problem, some restrictions are needed on the amount and eligibility of early withdrawals from pension savings. In the case of Fiji, early pension withdrawals are allowed for qualified life events - as well as for recovery from the damages caused by TC Winston in 2016 - up to 30 percent of the pension account balance in most cases (see Table 2).

Fiji's one-off pension withdrawals assistance for TC Winston in 2016 is likely to have improved welfare. Although estimating the welfare gain of this policy change depends on assumed parameter values and their precision, the model demonstrates that the benefit from more smoothed consumption in the year of being hit by a natural disaster would exceed the cost of eroded retirement savings. Panels A and B in Figure 2 illustrate the different paths of savings and consumption with and without the one-off withdrawal assistance (assuming that 
there is a disaster at the age of 44). In this illustrative scenario, there is a net positive welfare gain from the one-off withdrawals assistance, because of the much higher welfare gain from a smoother consumption path around the time of the natural disaster than the welfare loss from a lower consumption later, including during the retirement periods. ${ }^{11}$ While the size of the net welfare gain depends on parameter values and other model specifications, the conjecture that consumption smoothing following a natural disaster would exceed the cost of lower consumption for subsequent periods should hold in more general settings, provided that natural disasters cause a sizable income loss and force consumption to be very low, leading to a sharp rise in marginal utility of consumption.

\section{Committing to providing pension-withdrawal assistance whenever a natural disaster hits the economy could reduce households' precautionary savings. If households could} anticipate withdrawals whenever a natural disaster hits, pension savings would become more liquid than before. Therefore, households would no longer keep additional precautionary savings against natural disaster shocks. The model demonstrates that household savings would be exactly the same as the required pension contribution (Figure 2, Panel C). This essentially corresponds to the scenario that public insurance (withdraw option in this case) crowds out private insurance (self-insurance in case) discussed in literature (for example, Attanasio and Rios-Rull, 2000). Without any other policy changes, the welfare implications of committing to providing pension-withdrawal assistance is ambiguous: on one hand, households could enjoy a smoother life-time consumption path, leading to a welfare gain; on other hand, total savings may be lower which can be welfare-decreasing, considering the retirement needs or capital accumulation.

\section{Under such a committed pension withdrawals assistance, the mandatory pension contribution could be raised to further mitigate the under-saving problem. In this} pension scheme, increasing the mandatory pension contribution rates would put less constraints on households' ability to self-insurance than otherwise. Therefore, welfare could be improved by raising the level of the mandatory pension contribution, which further addresses the problem of under-saving for retirement, without jeopardizing self-insurance against natural disaster shocks (Figure 1, Panel C; the optimal contribution rate with recurrent early pension withdrawals, $\tau^{* *}$, is higher than that without early withdrawals, $\left.\tau^{*}\right)$. It should be noted that the financial sustainability of the pension fund is not a consideration here because Fiji has a defined contribution scheme.

\section{Caveats on the Model Analysis}

Drawing quantitative policy recommendations warrants caution. The optimal saving paths for households depend on different levels and characteristics of their life-time incomes, their survival probabilities that also depend on other key factors including health, and their preferences (i.e., assumed parameters of the utility function). In addition, estimating welfare

\footnotetext{
11 The detailed simulation results are provided in Appendix I.
} 
gains from consumption smoothing is also subject to these unknown and likely heterogeneous factors. Nonetheless, early pension withdrawals assistance could be more robust to these unknown factors than other more micromanaged social programs, because the decision of early withdrawal is decentralized to households who have more information on their own characteristics and situations.

We have focused on the case of a flat-rate contribution scheme, considering the practical difficulty in setting up more flexible and complicated contribution schemes. Although some flexible and state-contingent schemes could fully incentivize households to replicate the optimal saving path, it is hard in practice for the government to set up such a state-contingent scheme. Instead, a more prevailing practice is to set a flat-rate pension contribution requirement (i.e., a fixed share of income should be deposited in a pension account), as the Fiji government adopted. Setting a flat-rate pension contribution proportionate to income is a parsimonious but practically convenient way to address the issue of heterogenous life-time income levels across households.

There are also other possibly important aspects that the model in this paper does not capture. For instance, for simplicity, our theory does not take into account the impact of higher pension contribution rates on labor demand and supply. In addition, the early withdrawal policy may have some implications on financial stability. For example, in Fiji, FNPF's deposits in one commercial bank declined substantially after the pension members' early withdrawals. This caused a liquidity shortage for the bank. Lastly but not least, this analysis does not consider private insurance that can help contain the adverse effects from natural disasters. The private insurance markets are very small in Fiji and other Pacific island countries, though, indicating some existing barriers to such market-based insurance (Lucas 2015). 
Figure 1. Household saving decisions in the model

\section{Panel A. Under-savings by households ${ }^{1}$}

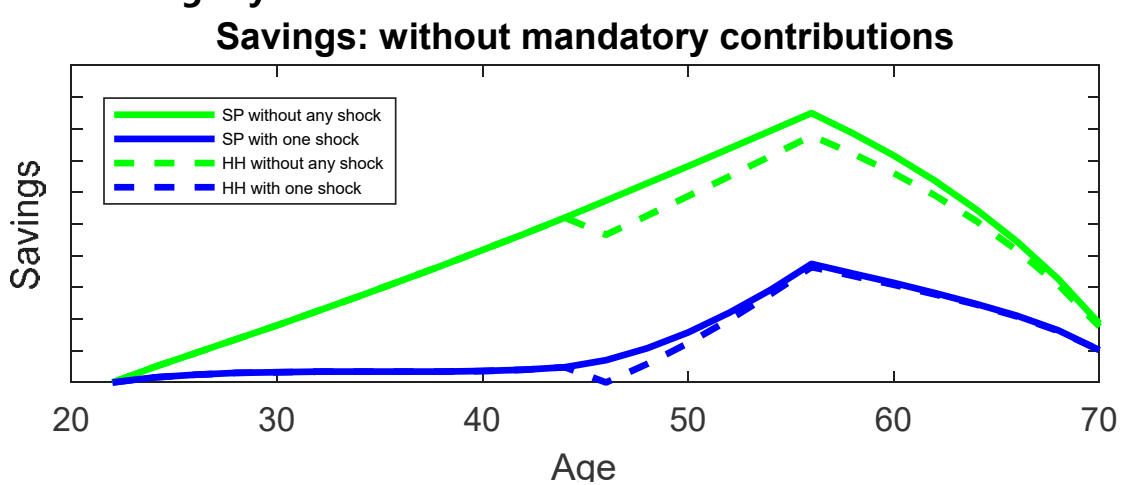

Panel B. Household saving under mandatory pension requirement ${ }^{2}$ Savings: with and without mandatory pension savings

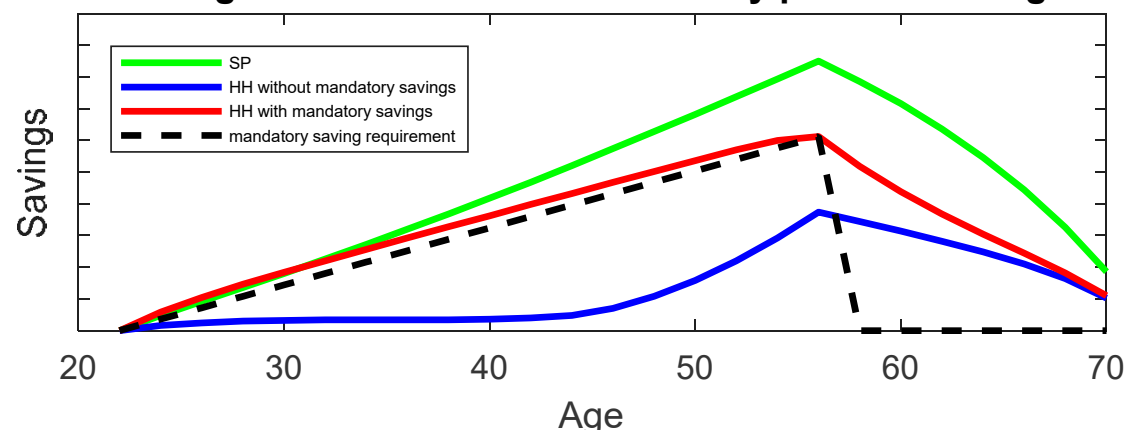

Panel C. Hump-shape relationship between welfare and the mandatory pension contribution rate $^{3}$

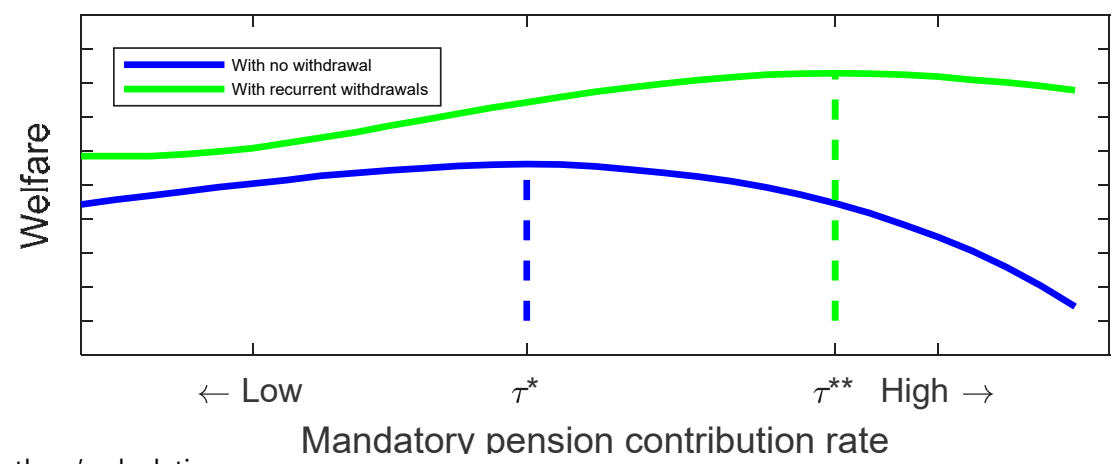

Source: the authors' calculations.

${ }^{1}$ The green solid line shows the path of savings over age without any incidence of a natural disaster based on the true survival rate $P_{s}$. The green dashed line is the path when a natural disaster occurs at an early age denoted by the disaster indicator (cross dots). The blue solid and dashed lines are the counterparts based on households' belief of a lower survival rate $P_{s}^{H}$. Both dashed lines show a saving reduction in the period following a natural disaster, to smooth consumption by making up for the income reduction in the period of a natural disaster.

${ }^{2}$ The green and blue solid lines show the path of savings over age without any incidence of a natural disaster based on the true survival rate $P_{s}$ and the lower survival rate $P_{s}^{H}$. The red solid line is the path with the lower survival rate $P_{s}^{H}$ and with the required pension contribution denoted by the black dashed line. The required contribution is set at the level that imitates the optimal saving level under the true survival rate $P_{S}$ at the retirement age.

${ }^{3}$ This is an illustrative figure to demonstrate the trade-off in a mandatory pension contribution scheme. Using the model, we simulate many life-time consumption paths corresponding to realizations of natural disaster shocks. Welfare is the expected life-time utility of households, calculated as the life-time utility averaged over the simulated consumption paths, for each mandatory contribution rate. See Appendix I for details. The blue line shows the case where pre-retirement withdrawals are prohibited and the green line shows the case where withdrawals are allowed upon a natural disaster. 
Figure 2. Household saving decisions in the model

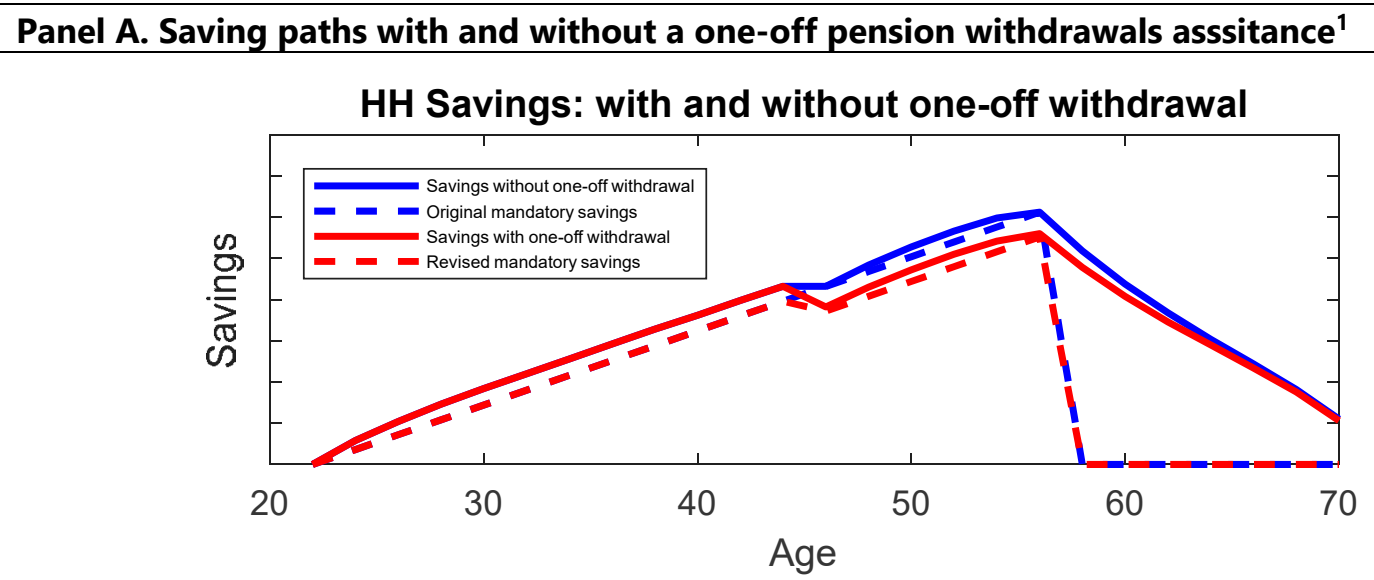

Panel B. Consumption paths with and without a one-off pension withdrawals asssitance ${ }^{1}$

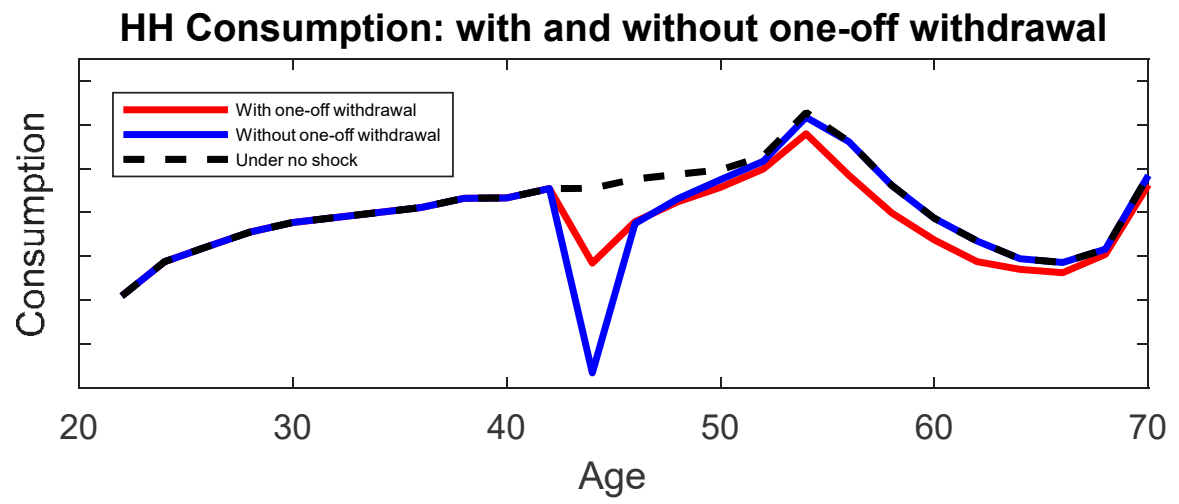

Panel C. When households anticipate pension withdrawals assistance following a natural disaster $^{2}$

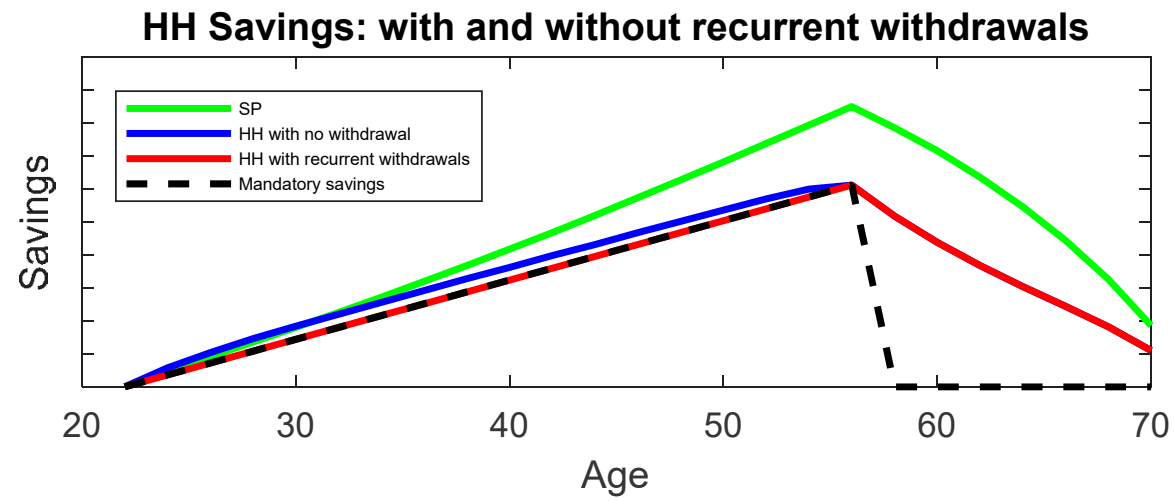

Source: the authors' calculations.

${ }^{1}$ The red lines correspond to the paths with a one-off pension withdrawals assistance following a natural disaster, while blue lines correspond to the paths without such an assistance.

${ }^{2}$ The green line shows the optimal saving path. The red line shows the saving path of households with the lower survival rate $P_{S}^{H}$, with the required pension contribution denoted by the black dashed line, and with no anticipation of pension withdrawals assistance following a natural disaster. The blue line shows the same saving path of households, but now with an anticipation of pension withdrawals assistance every time a natural disaster hits the economy. 


\section{Conclusions}

Motivated by Fiji's experience, this paper presents a theoretical analysis of the pension scheme design, considering natural disaster shocks. Both Fiji and Vanuatu used the early withdrawal of pension savings as a disaster relief measure. Assessing this policy contributes to the discussion on how to improve economic resilience against natural disasters. A lifecycle consumption-saving model with myopic households facing large natural disaster shocks demonstrates the key trade-off (in the pension scheme design) between building up sufficient retirement savings and ensuring the access to savings against natural disaster shocks.

In general, providing pension withdrawals assistance when being hit by a natural disaster could improve welfare. Allowing temporary withdrawals from locked pension savings helps households finance necessary expenditure when they recover from the damage caused by a natural disaster, leading to welfare gains. Making a commitment of providing such assistance whenever a natural disaster occurs would further improve welfare by reducing the need of additional precautionary savings against natural disaster shocks. However, the amount that can be withdrawn should be capped to safeguard the savings for retirement.

The recurrent use of the early withdrawal policy is likely to require an increase in the mandatory pension contribution rate. This is because households may decrease their (nonpension) savings if they anticipate that the pension savings can be used as emergency funds. On this front, Fiji increased the mandatory pension contribution rate from 16 percent to 18 percent in 2015, which is the highest among the region. However, the change of contribution rate was announced before 2016. It is likely that the increase was not calibrated to the early withdrawal policy started in $2016 .{ }^{12}$

Another option is to provide financial incentives to encourage savings. The incentives can follow the examples of 401(k) in the United States: each additional dollar of contributions to the pension funds from individuals would be matched with subsidy from employers (or government). This is likely to also increase the contributions to the voluntary saving accounts. Conceptually, the objective of increasing savings does not have to be achieved via the pension fund vehicle. However, for the consideration of minimizing operational cost, it is likely to be easier to start with augmenting the pension funds (which already exist in many small island countries) before setting up a separate fund.

A higher share of liquid foreign assets in the pension fund investment portfolio is needed to complement the early withdrawal policy. In the case of Fiji, the FNPF currently places less than 10 percent of its total assets in offshore investment, and thus, most of pension savings are not backed by foreign assets. This is likely to limit the effectiveness of

\footnotetext{
${ }^{12}$ The early withdrawal policy was announced unexpectedly after Cyclone Winston in February 2016.
} 
early pension withdrawal as a shock absorber, because at the aggregate level, the loss of national income in bad years needs to be compensated by using net foreign assets accumulated in good years to finance imports. ${ }^{13}$ Having pension savings backed by liquid foreign assets ex-ante would help meet this need of foreign assets in bad years.

${ }^{13}$ If the FNPF cannot increase its investment abroad, the foreign exchange will be held by RBF as reserves. In theory, the higher import needs after disasters can be financed either by a drawdown in the FNPF assets (when it holds offshore assets) or a decline in RBF reserves (when the FNPF only holds domestic assets). However, this equivalency may be hampered by the exchange restrictions. Moreover, the return from reserve assets may be lower than the returns from pension funds' offshore investment (given risk and return considerations). 


\section{Appendix I. Full Model Description}

We set up a finite-period discrete-time household problem with income shocks that capture large and unpredictable natural disaster shocks. Households, with no heterogeneity, maximize the discounted sum of a flow utility from consumption in each period with inelastic labor supply. Each person works for $K$ periods. In normal periods when no natural disaster occurs, labor income is assumed to be constant $\overline{y_{W}}$. If a natural disaster occurs, there will be an income loss of $\overline{D_{c}}$. A natural disaster randomly occurs with small probability $p$, with no predictability. After the retirement period $K+1$, households receive a basic substance income $\overline{y_{R}}$, which is lower than labor income but independent of natural disaster shocks. Households face survival rate $P_{S}$ in each period and live up to $T$ periods at maximum. Households face a zero-borrowing constraint and make savings for retirement and self-insurance against natural disaster shocks.

A key assumption is that households underestimate their survival probability in making the saving decision. Households believe that their survival rate is $P_{s}^{H}$, which is lower than the true value $P_{s}$. This assumption provides a rationale for mandatory pension schemes, which otherwise would be distortive to the optimal private decision making. To compute the optimal saving path of the social planner, we use the true value $P_{S}$ in solving the household problem, while we use $P_{s}^{H}$, instead, to analyze households' saving behaviors in the decentralized economy.

The representative household's problem is recursively formulated as follows (with survival rate $P_{S}^{H}$ ). Suppose households maximize the expected life-time utility, with time discount factor $\beta$ and a one period utility function with a degree of constant relative risk aversion (CRRA), denoted by parameter $\gamma$ :

$$
u\left(c_{t}\right)=\frac{c_{t}^{1-\gamma}-1}{1-\gamma}
$$

where $c_{t}$ denotes consumption at time $t$. In the standard recursive formulation, for $t=$ $1, \ldots, T$, the value function $V_{t}\left(a_{t}, d^{t}\right)$ for households at time $t$ with asset level $a_{t}$ and disaster history $d^{t}=\left(d_{s}\right)_{s=1, \ldots, t}$, where $d_{t}$ denotes the disaster shock indicator, solves:

$$
V_{t}\left(a_{t}, d^{t}\right)=\max _{\left\{c_{t}, a_{t+1}\right\}} u\left(c_{t}\right)+\beta P_{s}^{H} E\left[V_{t+1}\left(a_{t+1}, d^{t+1}\right)\right],
$$

subject to the budget constraint with the market interest rate $r$ (given to this model):

$$
\begin{aligned}
c_{t}+a_{t+1} & =(1+r) a_{t}+y_{t}-D_{c}\left(d_{t}\right), \\
y_{t} & = \begin{cases}\overline{y_{W}} & \text { if } t \leq K \\
\overline{y_{R}} & \text { if } t>K\end{cases}
\end{aligned}
$$


where $y_{t}$ denotes income and $D_{c}\left(d_{t}\right)$ denotes an income loss that takes a positive value $\overline{D_{c}}$ only when a shock hits the economy, formulated as follows:

$$
D_{c}\left(d_{t}\right)=\left\{\begin{array}{ll}
0 & \text { if } d_{t}=0 \\
\overline{D_{c}} & \text { if } d_{t}=1
\end{array}, \quad d_{t+1}=\left\{\begin{array}{ll}
0 & \text { with probability } 1-p \\
1 & \text { with probability } p
\end{array} .\right.\right.
$$

The maximization problem is also subject to a mandatory pension requirement $\overline{a_{t+1}}\left(d^{t}\right)$, if any, together with the zero-borrowing constraint:

$$
a_{t+1} \geq \overline{a_{t+1}}\left(d^{t}\right) \geq 0 .
$$

Note that households can save more than required, if they want to. We set the terminal value of the problem to zero (i.e., $V_{T+1}\left(a_{T}, d^{T}\right)=0$ ), assuming no motivation to leave a bequest.

We examine pension schemes with different withdrawal policies. As discussed in the main text, we focus on pension schemes of the form of flat-rate mandatory savings (i.e., defined-contribution pension with a constant rate of contribution relative to labor income), where a fixed share $\tau$ of labor income should be deposited in a pension account until the retirement age. After retirement, households can use the deposits and investment proceeds at their discretion. We also allow for withdrawals assistance at the time of natural disasters. Specifically, the mandatory pension saving requirement, $\overline{a_{t+1}}\left(d^{t}\right)$, takes the following form:

$$
\overline{a_{t+1}}\left(d^{t}\right)=\left\{\begin{array}{ll}
\tau\left[\sum_{s=1}^{t} y_{s}\right]-w_{t}\left(d^{t}\right) & \text { if } t \leq K \\
0 & \text { if } t>K
\end{array},\right.
$$

where $w_{t}\left(d^{t}\right)$ denotes the reduction in mandatory savings depending on the history of natural disaster shocks, which captures withdrawals assistance. It is kept at zero in a scheme that prohibits early withdrawals. One-off withdrawal assistance can be described as an unexpected change in $w_{t}\left(d^{t}\right)$ from zero to a fixed amount $\Delta$ in the wake of a natural disaster (aiming to imitate the Fiji's one-off pension withdrawals assistance for TC Winston in 2016). We further consider a recurrent natural disaster assistance, where households can get a pension withdrawals assistance whenever a natural disaster hits and households fully take it into account ex-ante. This policy can be captured by setting:

$$
w_{t}\left(d^{t}\right)=\sum_{s=1}^{t} \Delta d_{s}
$$

This scheme does not require replenishment of the amount withdrawn under the assistance.

We solve the model numerically. We modify the MATLAB ${ }^{\circledR}$ codes provided by Winter, Schlafmann, and Rodepeter (2012) to numerically solve this problem by value function 
iteration combined with backward induction. We introduce mandatory savings (or a timevarying minimum floor on the asset position) among others. The assumed specific parameter values are listed in Table A1. Note that one model period corresponds to 2 years, to reduce the computation burden.

\begin{tabular}{|cll|}
\hline Parameter & \multicolumn{2}{c|}{ Table A1. Parameter values used in the stimulation } \\
Description & \multicolumn{1}{c|}{ Value (with explanation $)$} \\
\hline$t$ & One period in the model & 2 years \\
$T$ & The number of the periods in the life time & $25(=50$ years, starting at age 20$)$ \\
$K$ & The number of working periods & $17(\simeq 35$ years, retired at age 55$)$ \\
$\beta$ & Households' time discount factor & $0.96\left(\simeq 0.98^{2}\right)$ \\
$\gamma$ & CRRA coefficient of the utility function & 2 \\
$\overline{y_{W}}$ & One-period income flow when working & $2(=1$ for one year $)$ \\
$\overline{y_{R}}$ & One-period income flow after retirement & $0.8(=0.4$ for one year $)$ \\
$D_{c}$ & Income loss due to a natural disaster & $-1.2(=60$ percent loss of labor income $)$ \\
$p$ & One-period probability of a natural disaster & $0.154(\simeq 8$ percent per year; Lee et al., 2018$)$ \\
$P_{S}$ & True one-period survival probability & $0.98(\simeq 0.99$ for one year $)$ \\
$P_{S}^{H}$ & Subjective one-period survival probability & $0.75(\simeq 0.86$ for one year $)$ \\
$\tau$ & Mandatory pension contribution rate & 18 percent of labor income \\
$\Delta$ & The size of each withdrawals assistance & $0.6(=60$ percent of annual labor income $)$ \\
& & \\
& Source: Authors' assumptions & \\
\hline
\end{tabular}

We use model simulations to examine different pension schemes and households' consumption-saving choices under those schemes.

- $\quad$ First, we set the mandatory pension contribution rate $\tau$ at zero for all periods to illustrate myopic households' behaviors in the model, compared to those under the social planner's optimal choices (Figures 1, Panel A in the main text). Then, we set $\tau$ at 18 percent, which is a statutory rate in Fiji. We assume there is no early withdrawal assistance to illustrate the tension between saving needs for retirement and liquidity needs for natural disaster shocks (Figure 1, Panel B in the main text).

- Second, to examine the effects of an unexpected one-off withdrawals, we simulate the path of savings and consumption, with the assumption that the mandatory saving requirement will be unexpectedly lowered by $\Delta$ from the disaster year and afterwards assistance (Figure 2, Panels A and B).

- $\quad$ Third, the implications of the recurrent use of withdrawals assistance is examined using the same $\tau$ and $\Delta$, while $w_{t}\left(d^{t}\right)$ is set in the above-mentioned way (Figure 2, Panel C). A key assumption of this scenario is that the early withdrawals assistance is expected by households.

For welfare comparison, we combine nonrandom and simulation-based numerical integrations to calculate the expected life-time utility of households. In theory, calculating the expected life-time utility requires taking the probability-weighted average over all possible histories of shock realizations over the life time $\left(d^{T}\right)$. In our model, the total number 
of the histories is $2^{T}\left(=2^{25} \simeq 34\right.$ million in our parametrization), which is too many and computationally challenging to conduct nonrandom calculation of the expected utility from the probability-weighted average of utility over all the possible histories. To overcome this problem, we apply this nonrandom calculation over all possible histories for only part of the histories, and use simulation-based numerical integration for the rest.

- First, we divide the expected utility into the conditional expected utility based on the number of occurrence of shocks $m(=0,1, \ldots, T)$ during the entire period:

$$
\begin{gathered}
E\left[U\left(d^{T}\right)\right]=\sum_{m=0}^{T} P\left(\sum_{t=1}^{T} d_{t}=m\right) E\left[U\left(d^{T}\right) \mid \sum_{t=1}^{T} d_{t}=m\right] \\
U\left(d^{T}\right)=\sum_{t=1}^{T} \beta^{t-1} P_{s}^{t-1} u\left(c_{t}\left(d^{t}\right)\right)
\end{gathered}
$$

where $U\left(d^{T}\right)$ denotes life-time utility given a realization of shocks $d^{T} ; c_{t}\left(d^{t}\right)$ denotes consumption at time $t$ given a realization of shocks $d^{t}$ up to time $t$; and $P\left(\sum_{t=1}^{T} d_{t}=m\right)$ denotes the probability of being hit by a natural disaster for $m$ times during the life time.

- $\quad$ Then we calculate the conditional expected utility for each $m$. We do so in a nonrandom way, by taking the probability-weighted averages of utility over all possible histories of shocks, for $m$ with the number of histories less than 1,000, and for $m$ with the number of histories less than 200,000 and probability $P\left(\sum_{t=1}^{T} d_{t}=m\right)$ is more than 0.1 percent.

- $\quad$ For the rest, we compute simulation-based numerical integrals over 1,000 samples of histories (generated by MATLAB ${ }^{\circledR}$ function "randperm" for each $m$ ).

This combined procedure not only reduces the computation burden but also increases accuracy. It reduces the number of histories of shocks to be examined, in our case, from 34 million to 262 thousand - a reduction of a factor of 128 . The nonrandom part of calculation covers 92 percent of the histories of shocks, without sampling errors due to simulations. The simulation-sampling errors exist only for the rest of 8 percent of the histories of shocks. This leads to smoother results with higher accuracy (roughly speaking, reducing sampling errors by a factor of 3 ), compared to the case where simulation-based numerical integration is applied to the whole space of shock histories (keeping the number of loops the same, i.e., 262 million).

Using this method, we plot welfare as a function of mandatory pension contribution rate $\boldsymbol{\tau}$. We let $\tau^{*}$ and $\tau^{* *}$ denote the optimal contribution rates that attain the maximum welfare for the case of no withdrawals assistance and the case of recurrent withdrawals assistance, respectively (Figure 1, Panel C). 


\section{Reference}

Attanasio, P., Rios-Rull, J. (2000). Consumption smoothing in island economies: Can public insurance reduce welfare? European Economic Review, 44(7), 1225-58.

Cole, S., Giné, X., Tobacman, J., Topalova, P., Townsend, R., and Vickery, J. (2013). Barriers to household risk management: Evidence from India. American Economic Journal: Applied Economics, 5(1), 104-35.

Fiji National Provident Fund (2016). Annual Report.

International Monetary Fund (2016). Vanuatu: 2016 Article IV Consultation Staff Report. IMF Country Report No. 16/336.

Karlan, D., Osei, R., Osei-Akoto, I., \& Udry, C. (2014). Agricultural decisions after relaxing credit and risk constraints. The Quarterly Journal of Economics, 129(2), 597-652.

Lee, D, Zhang, H, and Nguyen, C. (2018). The Economic Impact of Natural Disaster in Pacific Island Countries: Adaptation and Preparedness. IMF Working Paper.

Lucas, B. (2015). Disaster risk financing and insurance in the Pacific (GSDRC Helpdesk Research Report 1314). Birmingham, UK: University of Birmingham.

Mahul, O., Cook, S., and Bailey, B. (2015). Advancing Disaster Risk Financing \& Insurance in the Pacific. Washington D.C.: World Bank.

Mansur, A., Doyle, J., and Ivaschenko, O. (2017). Social Protection and Humanitarian Assistance Nexus for Disasters Response: Lessons Learnt from Fiji's Tropical Cyclone Winston. Social Protection and Labor Discussion Paper \#1701, World Bank.

Reserve Bank of Fiji (2016). Financial Inclusion Indicators.

Winter, Joachim, Kathrin Schlafmann, and Ralf Rodepeter (2012). Rules of Thumb in Life-cycle Saving Decisions. The Economic Journal, 122(560): 479-501. 